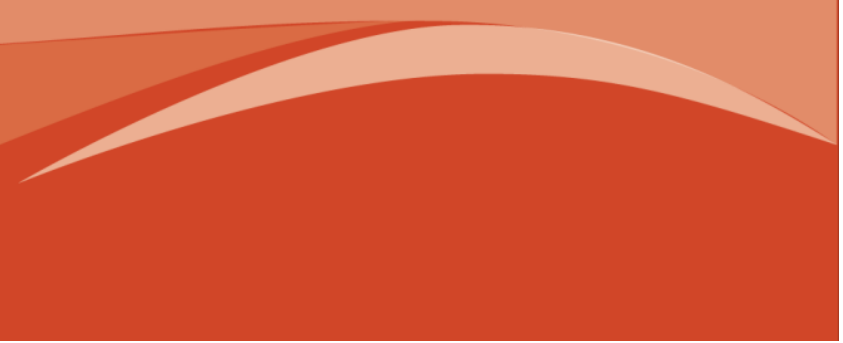

\title{
Consumo, consumismo e seus aspectos transversais: uma revisão de literatura
}

\author{
Consumption, consumerism and its cross-cutting aspects: a literature \\ review
}

\section{Consumo, consumismo y sus aspectos transversales: una revisión de la literatura}

\author{
Débora Cristina Vasconcelos Aguiar $^{\mathrm{a}} \mathbb{D}^{\mathbb{D}}$; Francisca Denise Silva do Nascimento $^{\mathrm{b}}$ \\ a Psicóloga pela Universidade Federal do Ceará - Campus de Sobral; mestranda em Educação pela UFC e bolsista do CNPq. \\ Universidade Federal do Ceará, Sobral, CE, Brasil - E-mail: debbiecva@hotmail.com \\ ${ }^{\text {b }}$ Doutora, Mestre e Graduada em Sociologia pela UFC. Professora do curso de Psicologia e do Mestrado em Saúde da Família da \\ Universidade Federal do Ceará - Campus de Sobral; Sobral, CE, Brasil - E-mail: denisesn1301@gmail.com
}

\begin{abstract}
Resumo: O presente trabalho consiste em uma revisão de literatura sobre os principais aspectos que compõem e atravessam os fenômenos do consumo e do consumismo, tais como mercadoria, identidade, cidadania, distinção, felicidade, mídia e ideologia. A proposta deste texto é realizar um diálogo entre diversas teorias que versam sobre o consumo, baseado em uma compreensão dialética da realidade. A partir das obras de autores como Bauman, Baudrillard, Bourdieu, Campbell, Canclini, Lipovetsky, Marx, Adorno, Horkheimer, Thompson, Guareschi, entre outros, buscamos compreender as características e interfaces que estruturam as sociedades atuais, também chamadas de sociedade de consumo e, por conseguinte, os modos de vida e sociabilidades produzidos por essas sociedades.
\end{abstract}

Palavras-chave: Consumo. Consumismo. Sociedade de consumo.

\begin{abstract}
The present work consists of a literature review about the main aspects that compose and cross-cut the phenomena of consumption and consumerism, such as merchandise, identity, citizenship, distinction, happiness, media and ideology. The proposal of this text is to conduct a dialogue between several theories that deal with consumption, based on a dialectical understanding of reality. Based on the works of Bauman, Baudrillard, Bourdieu, Campbell, Canclini, Lipovetsky, Marx, Adorno, Horkheimer, Thompson, Guareschi, among others, we try to understand the characteristics and interfaces that structure the present societies, also called consumer society and, hence, the ways of life and sociability produced by these societies.
\end{abstract}

Keywords: Consumption. Consumerism. Consumer society.

Resumen: El presente trabajo consiste en una revisión de la literatura sobre los principales aspectos que componen y abarcan los fenómenos del consumo y el consumismo, tales como mercancías, identidad, ciudadanía, distinción, felicidad, medios e ideología. La propuesta de este texto es llevar a cabo un diálogo entre varias teorías que se ocupan del consumo, basado en una comprensión dialéctica de la realidad. Basados en los trabajos de Bauman, Baudrillard, Bourdieu, Campbell, Canclini, Lipovetsky, Marx, Adorno, Horkheimer, Thompson, Guareschi, entre otros, intentamos comprender

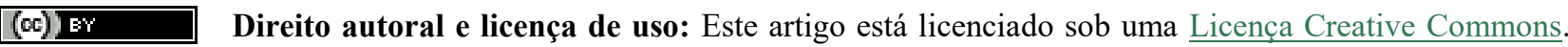
Com essa licença você pode compartilhar, adaptar, para qualquer fim, desde que atribua a autoria da obra, forneça um link para a licença, e indicar se foram feitas alterações. 
las características e interfaces que estructuran las sociedades actuales, también llamadas sociedad de consumo y, de ahí, los modos de vida y sociabilidad producidos por estas sociedades.

Palabras clave: Consumo. Consumismo. Sociedad de consumo.

Como citar o artigo:

AGUIAR, D. C. V; NASCIMENTO, D. S. N. Consumo, consumismo e seus aspectos transversais: uma revisão de literatura. Revista de Ciências Humanas, Florianópolis. v.52. 2018. DOI: 10.5007/2178-4582.2018.54740

\section{INTRODUÇÃO}

"Mais vale dar fim que consertar. Quanto mais se remenda, menos se aproveita." (HUXLEY, 2009, p. 92). Esta frase tão repetida na ficção Admirável Mundo Novo também se mostra presente em nosso contexto atual, em que o consumo se apresenta como atividade central das sociedades capitalistas. A expressão "sociedade de consumo" é usada por vários autores, dentre eles Baudrillard (2014), Bauman (2008), Debord (2003), Lipovetsky (2007) e Canclini (1997), para descrever as características destas sociedades, seu surgimento e suas transformações. Entre as características elencadas e compartilhadas por estes autores, destacamos: o culto ao novo; o descarte e o desprezo ao velho ou ultrapassado; a obsolescência e efemeridade dos produtos, com a crescente brevidade de seu tempo de vida útil ou valor social e; a mercantilização da vida, que condiciona todas as atividades ou ocasiões do cotidiano das pessoas à prática do consumo.

Bauman (2008) e Lipovetsky (2007) contam que, na fase inicial do capitalismo, a atividade central das sociedades era o trabalho, sendo este muitas vezes considerado como um fim em si mesmo, enquanto o consumo, para a maioria da população, era algo secundário e estava voltado à subsistência. Com os avanços da automação e o grande aumento da produção de mercadorias, o consumo em larga escala foi ofertado e incitado a todas as camadas sociais, ainda que de forma hierárquica e segregatícia. Deste modo, o consumo, induzido e incentivado pelos meios publicitários, foi ganhando cada vez mais espaço na vida das pessoas, de forma que ele passou a contemplar todas as áreas da vida social, adquirindo significados e sentidos sociais e privados, que definem, distinguem, organizam e compõem a vida e a subjetividade das pessoas. Bauman (2008) dividirá essa transformação da sociedade em dois momentos: o primeiro marcado pela sociedade de produtores e o segundo pela sociedade de consumo ou de consumidores. Já Lipovetsky (2007) a divide em três fases, sendo a primeira ainda rudimentar, marcada pelos primeiros esforços da indústria, das marcas e da publicidade em se consolidarem, cujo alvo ainda era a burguesia; a segunda marcada pelo boom do consumo de massa com o advento do fordismo e a ruptura cultural dos anos 1960 e; a terceira, que seria o momento atual, ou a sociedade de hiperconsumo, revela os excessos do nosso tempo. 
Campbell (2001) atenta também para a necessidade de uma ética que explicasse a mudança dos valores culturais, possibilitando a emergência do consumismo, já que para ele apenas o aumento da produção não justificava a transformação de consumidores regrados e moderados em consumidores conspícuos. De acordo com este autor, o puritanismo, apontado por Weber como fundamental para o aumento e concentração do capital, por pregar uma vida absenta de prazeres e luxos, foi oposto por uma ética romântica que rejeitou os estritos valores puritanos e valorizou modos de viver mais liberais e hedonistas, contribuindo, assim, para a preponderância de uma cultura do consumo. Baudrillard (2014), por outro lado, considera que o puritanismo não foi essencial apenas para a acumulação capitalista, mas também para fundamentar uma moral do consumo, sendo este, parte ou complemento do processo de produção, logo, consumir também se trataria de um dever. A moral consumista de Baudrillard (2014) diverge da ética romântica de Campbell (2001) por sustentar que, após a solidificação dessa moral consumista, ocorreu um revezamento entre o puritanismo e uma moral voltada para os prazeres (como o dever de ser feliz) e não um afastamento ou oposição daquele em relação à ética romântica, como Campbell parece supor. Entretanto, ambos os autores convergem em relação à existência de um sistema moral ou ético que embase essa cultura do consumo.

Assim, para compreender melhor a sociedade de consumo ou hiperconsumo, analisaremos alguns dos fatores relacionados a consumir, como identidade, cidadania, distinção e felicidade, além de explanarmos sua relação com a mídia e a ideologia.

\section{A MERCADORIA}

Tal como Marx (2012), começaremos este traballho falando sobre a mercadoria, já que, para ele, a riqueza nas sociedades capitalistas pode ser compreendida como uma enorme coleção de mercadorias. Consoante Marx (2012, p. 113), “A mercadoria é, antes de tudo, um objeto externo, uma coisa que, por meio de suas propriedades, satisfaz necessidades humanas de um tipo qualquer".

Para o autor, a mercadoria possui um duplo valor: o valor de uso (referente à qualidade) e o valor de troca (referente à quantidade) ou forma de valor. O valor de uso é aquele expresso no processo de consumo e que está atrelado à utilidade de determinada coisa. Já o valor de troca ou a forma de valor se refere ao quantum de trabalho que foi despendido para a produção de uma mercadoria em um determinado tempo. Logo, segundo Marx (2008, 2013), o valor de uma mercadoria corresponde ao tempo médio de trabalho humano geral abstrato utilizado para produzir determinada mercadoria em condições normais de produção.

Apesar disso, Marx (2012) considera que as mercadorias apresentam um caráter místico ou fetichista, indexado em seu valor de troca, pois são atribuídas às mercadorias relações sociais que são 
próprias das pessoas, enquanto a estas são atribuídas relações reificadas ou materializadas no tempo de trabalho empregado, como se elas fossem objetos ou coisas a serviço do capital. Portanto, o caráter fetichista da mercadoria está relacionado à divisão do trabalho nas sociedades capitalistas, em que o trabalhador não se reconhece na mercadoria que produz, e esta, quando concluída, aparece como se tivesse sido feita "em um passe de mágica" e não como fruto de seu trabalho. Deste modo, o trabalhador se relaciona com o produto de seu trabalho de maneira reificada ou materializada, recebendo um pagamento pelo tempo de trabalho, e a mercadoria, por sua vez, é vista como algo "sensível-suprassensível"1 ou dotada de características sobrenaturais, que fazem com que ela valha mais do que o tempo empregado na sua produção. Além disso, as mercadorias ganham características sociais que são percebidas como se fossem intrínsecas a elas, como felicidade, juventude e beleza, e que muitas vezes são exploradas pela publicidade e pela propaganda ${ }^{2}$ que vendem essas mercadorias por essas relações ou imagens que elas representam, como se o consumo dessas pudesse milagrosamente incorporar tais atributos ao seu consumidor.

Outro autor que fala sobre o fetichismo da mercadoria é Guy Debord, que reafirma muito do que foi postulado por Marx. De acordo com Debord (2003), o princípio do fetichismo da mercadoria fala de uma sociedade dominada por “coisas suprassensíveis embora sensíveis". Em suas palavras: “O mundo sensível é substituído por uma seleção de imagens que existem acima dele, ao mesmo tempo em que se faz reconhecer como o sensível por excelência” (DEBORD, 2003, p. 29). Compreendemos com isto que às mercadorias são atribuídas imagens ou elementos "suprassensíveis", na forma de representações e significados, que são expostos de forma espetacularizada, estando para além do seu valor de uso. Este duplo valor da mercadoria, compreendido como seu valor utilitário e o valor que lhe foi atribuído socialmente, também pode ser observado na ficção de Huxley por meio do seguinte trecho: "Mas o valor de uma coisa não está na vontade de cada um. A sua estima e dignidade vêm tanto do seu valor real, intrínseco, como da opinião daquele que a tomou." (HUXLEY, 2009, p. 361). Entretanto, apesar dessas imagens construídas, as mercadorias continuam sendo coisas comuns e, como tais, são passíveis de troca ou descarte.

Outro ponto salientado por Debord (2003) é o fato de que o grande aumento da produção de mercadorias e a falta de "consumidores ideais" causaram algumas mudanças no modo como se concebia a sociedade e o consumo. A primeira grande mudança que percebemos é a forma de participação das classes menos favorecidas, ou dos proletários, no consumo. Antes "os proletários"

\footnotetext{
${ }^{1}$ Essa expressão faz referência à fala de Mefistófeles em Fausto, de Goethe (primeira parte, "No jardim de Marta”): “Tu, conquistador sensível, suprassensível,/ Uma mocinha te conduz pelo nariz".

${ }^{2}$ Vale salientar que propaganda refere-se ao ato de propagar, divulgar, comunicar ideias, produtos e crenças com ou sem fins comerciais, enquanto publicidade trata da comunicação comercial, com ou sem fins lucrativos, visando tornar público ou promover produtos, serviços, entre outros, utilizando-se de meios de comunicação e de setores especializados em técnicas de divulgação.
} 
eram vistos apenas como operários, recebendo o mínimo necessário para a conservação da sua força de trabalho. Depois, com a segunda revolução industrial, "o consumo alienado", nos termos de Debord, "torna-se para as massas um dever suplementar à produção alienada" (DEBORD, 2003, p. 32-33). O operário que no trabalho é desprezado e maltratado se vê cada vez mais do lado de fora, aparentemente valorizado e bem-tratado como um possível consumidor. Nesse sentido, de acordo com Debord (2003), semelhantemente ao que foi expresso por Baudrillard (2014), o consumo para o operário se torna um dever disfarçado de privilégio.

A segunda grande mudança percebida é o aumento daquilo considerado necessário à sobrevivência, o que, para o autor, está relacionado à constante fabricação de pseudonecessidades, que por sua vez, serve a outra pseudonecessidade, que é a manutenção da economia. Esse fenômeno chamado por Debord (2003) de "sobrevivência aumentada" amplia o sentido da sobrevivência em sua forma mais simples, como comer e habitar, para compreender aspectos relacionados aos lazeres e à humanidade do trabalhador, ou à totalidade da existência humana. Nessa perspectiva, todos os aspectos da vida se tornam dependentes de mercadorias e a quantidade de consumo indica qualidade de vida. Debord (2003) demonstra essa questão com o seguinte aforismo: “O espetáculo é o momento em que a mercadoria chega à ocupação total da vida social” (DEBORD, 2003, p. 32).

Além disso, ainda segundo Debord (2003), o valor de troca deixou de ser agente do valor de uso e ganhou papel principal na atividade do consumo. Ao se considerar que o consumo gera satisfação, o valor de uso de um produto se tornou secundário para o monopólio da satisfação, pois o que importa é consumir (enquanto troca). Por isso, o valor de uso deve estar "proclamado na realidade invertida do espetáculo" (DEBORD, 2003, p. 56) como uma forma de pseudojustificação disso que se torna secundário para o consumo, mas necessário à "falsa vida" (DEBORD, 2003, p. 36). Logo, para o autor, "O consumidor real torna-se um consumidor de ilusões. A mercadoria é esta ilusão efetivamente real, e o espetáculo a sua manifestação geral" (DEBORD, 2003, p. 36). Além do caráter ilusório presente no valor de troca, o fetichismo da mercadoria para o autor, tal como para Marx, consiste na teoria de que são atribuídas relações sociais às mercadorias e relações reificadas às pessoas, como podemos observar na citação a seguir:

A consciência do desejo e o desejo da consciência são um mesmo projeto que, sob a sua forma negativa, quer a abolição das classes, isto é, a posse direta pelos trabalhadores de todos os momentos da sua atividade. O seu contrário é a sociedade do espetáculo onde a mercadoria se contempla a si mesma num mundo que ela criou. (DEBORD, 2003, p. 38)

Portanto, Debord (2003) concebe, usando termos psicanalíticos, que a sociedade do espetáculo consiste na não consciência do desejo ou no não desejo da consciência, na alienação que está relacionada tanto aos meios de produção, ao produto final, ao conhecimento do processo de produção, como também à alienação de si, dos seus desejos e da sua condição de sujeito e da adequação a esse 
sistema. Em uma sociedade onde as pessoas não se questionam sobre a sua condição e os seus desejos, onde são colocadas na posição de objeto, as mercadorias é que, ganhando características sociais através do fetiche, tornam-se valorizadas. Assim sendo, cabe entendermos como se configura o consumo dessas mercadorias em nossas sociedades.

Em consonância com esta visão, Maingueneau (2001, p. 208) atenta para as seduções do discurso da marca, ao demonstrar como esta, na forma de uma entidade, "desempenha um papel de conceptor do produto, responsável por sua qualidade". Além disso, o autor ressalta que a marca cada vez mais "se desliga do estatuto de fabricante de produtos para se tornar um princípio muito abstrato, produtor de discursos que lhe permitem investir em seus produtos um certo número de valores específicos: a seriedade, a juventude etc.” (MAINGUENEAU, 2001, p. 208). Logo, o nome da marca estaria relacionado às representações construídas em torno dela, que por sua vez estão relacionadas aos discursos e enunciados que ela produz, por meio das estratégias da publicidade, que reforçam, sustentam e modificam a imagem da marca no imaginário social, sendo esta marcada pelo fetiche da mercadoria.

\section{CONSUMO, CONSUMISMO E IDENTIDADE}

Tendo discorrido sobre o conceito de mercadoria, nosso próximo passo é compreender os significados em torno do consumo, as diferenças entre consumo e consumismo e como se dá a construção da identidade e o reconhecimento desta mediante tal prática.

Comumente se distingue consumo de consumismo através dos objetivos e dos critérios utilizados para a compra de um produto. Assim, o simples consumo estaria relacionado a aquisições racionais e seletivas, enquanto consumismo seria o ato de comprar produtos sem algum critério de escolha, sem avaliar sua necessidade ou utilidade. Logo, o consumismo trataria da compra de coisas supérfluas e seria frequentemente relacionado ao papel que a publicidade e a propaganda exercem sobre as pessoas, induzindo-as ao consumo, independentemente de ser algo realmente necessário ou até mesmo útil (CORTEZ, 2009). Tal concepção de consumo como atrelado ao útil e consumismo ao inútil está relacionada aos conceitos de Marx, valor de uso, valor de troca e fetiche, de modo que as mercadorias teriam um valor simbólico além do valor de uso, e em alguns casos aquele parece superar sua utilidade, como foi comentado no tópico anterior. Logo, algumas compras seriam realizadas por utilidade enquanto outras, por fetiche.

O consumo desenfreado ou consumismo também é visto como o lado negativo do consumo e considerado como um dos principais problemas das sociedades industriais modernas. Com isso, a produção de mercadorias no sistema capitalista não estaria voltada simplesmente para suprir a 
demanda, mas criaria necessidades, de forma que é de seu interesse que as necessidades envelheçam para que surjam novas necessidades e as pessoas venham a consumir novamente e cada vez mais (ORTIGOZA, 2009).

Marx (2008) compreende consumo como um processo idêntico à produção, mantendo entre si uma relação dialética, pois quando produzo também estou consumindo, no sentido de desagaste dos materiais e dos meios de produção e quando consumo também estou produzindo ou reproduzindo, no sentido de gostos, modos de ser e necessidades. Logo, produção e consumo se retroalimentam, de modo que o consumo é tanto o fim da produção como também a impulsiona. Semelhantemente, a produção não cria apenas o objeto, mas também o modo de consumo, produzindo assim objetiva e subjetivamente. Como bem disse Marx (2008, p. 248), “A produção cria, pois, os consumidores.”.

Baudrillard (2014), baseando-se em Marx, realiza uma distinção entre o valor utilitário e o valor de signo, em que o primeiro estaria relacionado à satisfação de "necessidades naturais", isto é, aquelas de origem fisiológica ou natural, e o segundo trataria da satisfação das "necessidades artificiais", que seriam aquelas pertencentes a um sistema de necessidades e produzidas por meios simbólicos ou ideológicos. Por estarem situadas no campo do simbólico, as "necessidades artificiais" seriam, portanto, insaciáveis, pois, de acordo com o autor, tal como o sintoma na conversão histérica, o desejo se deslocaria e a pessoa viria logo a desejar outra coisa. O que estaria em questão nas necessidades artificiais não seria a satisfação das mesmas, mas a sua eterna insatisfação, a fim de que se promova a moral consumista. Assim, para Baudrillard (2014), o consumo nas sociedades contemporâneas não é uma necessidade natural, mas artificial.

Ainda sobre as necessidades, para o autor, não se trata apenas da produção de necessidades, como coisas isoladas, caso fosse assim, elas seriam rejeitadas e ignoradas pelas pessoas. Trata-se, portanto, da produção de um sistema de necessidades, por meio de signos e símbolos compartilhados coletivamente, que se baseia na moral consumista de que você precisa sempre de mais e de que nunca se tem o suficiente (BAUDRILLARD, 2014).

Assim, conforme Baudrillard (2014), explicar o consumo pela necessidade é uma tautologia ou um ato de ingenuidade. O consumo, por ter um componente estrutural simbólico, gerencia uma lógica social inconsciente, a lógica do desejo. O autor considera que as empresas de produção controlam o comportamento do mercado e, consequentemente, dos consumidores, mediante estratégias de publicidade que, vale ressaltar, nem sempre são bem recebidas. Salvo algumas exceções, esse controle se faz efetivo na maioria das vezes por sua dimensão inconsciente e pela coação social que o sujeito sofre que, com a intensificação do individualismo ${ }^{3}$, faz com que aquele

\footnotetext{
${ }^{3}$ Para Baudrillard (2014), a sociedade de consumo intensifica e reprime o individualismo, pois promove a atomização dos indivíduos consumidores com a busca da liberdade individual e da felicidade privada ao mesmo tempo em que exige dos mesmos certa preocupação social.
} 
se perceba como o único diferente, devendo se adequar ao sistema para poder ser aceito. Esse controle das atitudes em relação ao consumo efetuado pelas empresas é chamado pelo autor de "fieira invertida" e contrapõe a ideia do indivíduo como quem exerce o poder ou determina o que deve ou não ser consumido, como na "fieira clássica".

Baudrillard (2014) também critica algumas teorias psicossociológicas que atribuem ao consumidor o papel de vítima indefesa, como critica os que defendem a liberdade e soberania do consumidor. Para ele, são os signos e não os sujeitos que são manipulados, resultando no fato de que os sujeitos não são livres para escolher segundo o seu próprio desejo, já que são coagidos a agir conforme os modelos produzidos industrialmente, mas também não fazem isso de forma alienada, porque escolhem, em alguma medida, participar desse sistema. Logo, para Baudrillard (2014), o consumo se trata de uma conduta ativa, pois o consumidor tem que desenvolver atividade contínua para manter-se nesse sistema.

Além de Baudrillard, outros autores como Bauman e Lipovetsky, atentam para o valor social do consumo, além de seu valor utilitário. Esses autores, no entanto, não compreendem o valor social como necessidades artificiais ou pseudonecessidades, isto é, como inferiores às necessidades chamadas por eles como naturais ou reais, mas como aspectos inerentes ao processo de consumo e identificação, cuja importância também deve ser considerada, assim como os riscos e excessos desse processo.

Bauman (2008, p. 41) compreende o consumo como "característica e ocupação dos seres humanos como indivíduos" e também como "um investimento em tudo que serve para o valor social e a auto-estima do indivíduo" (BAUMAN, 2008, p. 76). Consumir significaria, também, "investir na afiliação social de si próprio, o que numa sociedade de consumidores traduz-se por "vendabilidade"” (BAUMAN, 2008, p. 75).

Para este autor, na sociedade de consumidores ninguém pode se tornar sujeito sem, antes, se tornar mercadoria e essa subjetividade deve ser "reanimada" ou "recarregada" perpetuamente através do consumo de mercadorias, que as identifiquem enquanto tais (BAUMAN, 2008, p. 20). Nessa perspectiva, o consumo seria capaz de valorar as pessoas, sendo as mercadorias consideradas instrumentos de identificação.

Já “consumismo", para Bauman (2008, p. 41), seria “um atributo da sociedade”, ou seja,

um tipo de arranjo social resultante das vontades, desejos e anseios humanos rotineiros, permanentes e, por assim dizer, "neutros quanto ao regime", transformando-os na principal força propulsora e operativa da sociedade, uma força que coordena a reprodução sistêmica, a integração e a estratificação sociais, além da formação de indivíduos humanos desempenhando ao mesmo tempo um papel importante nos processos de auto-identificação individual e de grupo, assim como na seleção e execução de políticas de vida individuais (BAUMAN, 2008, p. 41, grifo do autor). 
O consumismo é compreendido por Bauman como um excesso e um desperdício econômico, e, consequentemente, como uma economia do engano porque ele, nas palavras do autor, "aposta na irracionalidade dos consumidores e não em suas estimativas sóbrias e bem informadas, estimula emoções consumistas e não cultiva a razão" (BAUMAN, 2008, p. 15).

Posto isto, em uma sociedade de consumidores, as coisas não são feitas para durar, mas para serem trocadas por outras mais novas e mais atuais. O velho se tornou sinônimo de defasado e impróprio de continuar a ser utilizado, devendo, portanto ser jogado na lata do lixo, tal como o trecho de Admirável Mundo Novo supracitado "Mais vale dar fim que consertar. Quanto mais se remenda, menos se aproveita.” (HUXLEY, 2009, p. 92).

Ainda de acordo com Bauman (2008, p. 45), “o advento do consumismo augura uma era de 'obsolescência embutida' dos bens oferecidos no mercado e assinala um aumento espetacular na indústria da remoção do lixo". A "obsolescência embutida" supracitada trata de um fenômeno também chamado de obsolescência programada ou obsolescência planejada, em que os próprios fabricantes planejam o envelhecimento e desgaste dos seus produtos, isto é, limitam sua vida útil, a fim de aumentar o consumo. Também podemos perceber esse fenômeno na citação a seguir:

\footnotetext{
A curta expectativa de vida de um produto na prática e na utilidade proclamada está incluída na estratégia de marketing e no cálculo de lucros: tende a ser preconcebida, prescrita e instilada nas práticas dos consumidores mediante a apoteose das novas ofertas (de hoje) e a difamação das antigas (de ontem). (BAUMAN, 2008, p. 31).
}

Por conseguinte, para Bauman (2008), estamos vivendo em um novo modelo de sociedade, que não mais busca estabilidade e durabilidade, como a sociedade dos produtores, mas sim que visa estar em movimento, aproveitar o momento, e realizar o mais rapidamente possível seus desejos e necessidades, e, para tudo isso, é necessário consumir. Posto isto, é imprescindível que os consumidores não se satisfaçam com as mercadorias que consomem, mas que a insatisfação gerada pelo anúncio do novo, que supera e deprecia o produto ultrapassado, conduza os sujeitos a substituírem aquelas mercadorias ultrapassadas que viraram "estigma de vergonha" por novas mercadorias com suas promessas de felicidade.

Além disso, o consumo é tido como algo obrigatório para a sociedade de consumidores, independentemente de idade, gênero e de classe social; ela considera que todos devem ver e tratar o consumo como vocação ou como um direito e um dever universal. Você pode escolher consumir o que quiser, mas você precisa escolher algo. Com isso, os consumidores que não atendem ao apelo da cultura consumista se sentem inadequados, deficientes, ou abaixo do padrão, sendo, nos termos de Bauman, "consumidores falhos". Esses costumam estar presentes nas estatísticas sobre "os pobres" 
ou "as pessoas abaixo da linha de pobreza" e são percebidos como dignos de caridade e incapazes de escolher como os demais membros da sociedade (BAUMAN, 2008).

Ainda de acordo com Bauman (2005, 2008), as identidades não podem ser compreendidas como dadas ou obtidas pelo nascimento, mas adquiridas e sustentadas com esforço, construídas através das escolhas das pessoas, isto é, daquilo que elas consomem. Em suas próprias palavras: “Os bens de consumo dificilmente são neutros em relação à identidade; tendem a vir com o selo 'identidade incluída' (da mesma forma que produtos eletrônicos são vendidos com 'baterias incluídas').” (BAUMAN, 2008, p. 143). Isto significa que aquilo que consumimos diz de nós, daquilo que somos e do que queremos transmitir aos outros, de nossos gostos, preferências, identificações e, inclusive, de nosso poder aquisitivo.

Lipovetsky (2007) conflui com esta concepção ao afirmar que as pessoas não consomem apenas produtos, mas marcas, e que estas servem para identificar os consumidores, à medida que elas representam um conceito, um estilo de vida. Logo, segundo o autor, ao consumir marcas consideradas de qualidade, uma pessoa busca demonstrar que ela também é uma pessoa de qualidade. Para Lipovetsky (2007), a imagem aclamada pela dimensão da qualidade busca não apenas certo distanciamento em relação à maioria, o que por sua vez anseia por provocar inveja aos demais, mas também para não parecer menos que os outros.

Além da identidade, o consumo também pode ser considerado como forma de exercer a cidadania, o que será abordado no tópico a seguir.

\section{CONSUMO E CIDADANIA}

Observamos nos tópicos anteriores que os autores Debord e Baudrillard têm uma visão crítica sobre o consumo. Contudo, existem autores, como Bauman, Canclini e Lipovetsky, que consideram, além do aspecto crítico, o potencial criador e construtivo do consumo.

Canclini (1997), em seu livro “Consumidores e Cidadãos”, critica a ideia de que o consumo seria um desperdício ou um ato irracional. Ele considera que o consumo tem uma função social que está relacionada com a forma como as sociedades estão estruturadas e a posição que determinado consumidor ocupa nela. Para ele,

[...] o consumo é o conjunto de processos socioculturais em que se realizam a apropriação e os usos dos produtos. Esta caracterização ajuda a enxergar os atos pelos quais consumimos como algo mais do que simples exercícios de gostos, caprichos e compras irrefletidas, segundo os julgamentos moralistas, ou atitudes individuais, tal como costumam ser explorados pelas pesquisas de mercado (CANCLINI, 1997, p. 53). 
Para Canclini (1997), o novo por si só não seria objeto de desejo se não estivesse atrelado a uma cultura que atribui sentido as coisas. Assim, o consumo teria função tanto de distinção quanto de inclusão em determinados grupos, além de ser considerado como o principal procedimento de identificação. Longe de um ato irracional, o consumo, segundo o autor, serve para pensar.

Comprar objetos, prendurá-los ou distribuí-los pela casa, assinalar-lhes um lugar em uma ordem, atribuir-lhes funções na comunicação com os outros, são recursos para se pensar o próprio corpo, a instável ordem social e as interações incertas com os demais. Consumir é tornar mais inteligível um mundo onde o sólido se evapora (CANCLINI, 1997, p. 59).

Esta concepção de consumo como algo que possibilita a organização do sujeito também está presente em Lipovetsky (2007) ao considerar que consumir seria uma forma de ter maior poder sobre a vida e domínio sobre tempo, espaço e corpo. Em uma sociedade marcada pelo individualismo, o consumo também possibilita espaços de independência pessoal e o governo de si próprio mediante a realização de suas próprias escolhas.

Para Canclini (1997), além de fazer pensar, o consumo também estaria relacionado a um modo de se exercer a cidadania, pois, de acordo com o autor, vários fatores fizeram com que as pessoas procurassem outras formas de cidadania que parecessem muito mais representativas do que as formas políticas hegemônicas. Dentre esses fatores o autor destaca: a globalização no lugar da internacionalização e a substituição do local pelo global; a redefinição do senso de pertencimento e identidade, isto é, a perda de identidade nacional e a identificação com outros grupos internacionais (leiam-se norte-americanos); o descrédito no sistema político altamente burocrático e representativo de uma minoria que detém o poder e que também está submisso às regras do comércio, do espetáculo e da corrupção; o modo de organização das cidades cada vez mais populosas e em que se conhecem cada vez menos pessoas; a reelaboração do "próprio" como sendo algo particular (privado) e não como coletivo (nacional ou municipal) e; a passagem do cidadão com uma opinião pública para um cidadão cada vez mais interessado no seu bem-estar individual.

Os meios pelos quais isso se deu foram os meios midiáticos, nos quais as pessoas pareciam ter voz, poderiam apresentar suas opiniões de modo mais fácil e rápido. Isso, por sua vez, ocasionou novas formas de socialização, pois a mídia deslocava o desempenho da cidadania para as práticas de consumo, uma vez ela mesma estava sujeita aos ditames do lucro. Em sua forma de apresentar os fatos (como espetáculo), de justificar os acontecimentos (rápida e sem muito aprofundamento) e de expor modos de ser e consumir, através da publicidade e da propaganda, ela salientava a importância do consumo como forma de cidadania, de identificação e distinção, acabando por influenciar, principalmente, os mais pobres e menos instruídos (CANCLINI, 1997). 
Baudrillard (2014) também fala sobre a percepção do consumo como exercício da cidadania ao apontar para o fato de que a fieira invertida, compreendida como esse sistema de produção e consumo previamente determinado, completa o sistema eleitoral. Segundo o autor, isto ocorre porque o individualismo presente nas sociedades modernas, somado à moral consumista, corroboram para a compreensão do consumo como dever do cidadão. Além disso, a conotação atribuída ao consumo em algumas sociedades neoliberais faz com que ele seja compreendido muitas vezes como mais importante que a taxação de impostos, pois representaria um dever cívico para o crescimento da economia e também respeitaria a liberdade individual. Em suma, de acordo com o autor, o ato de consumir é também compreendido como exercício da cidadania, posto que, ao escolher, a pessoa toma decisões que atingem tanto a sua vida individual como também contribui com a dinâmica social.

Desse modo, compreendendo o consumo como um fenômeno que tem implicações sociais e individuais, nosso próximo passo é analisar o uso do consumo como uma ferramenta de distinção social.

\section{CONSUMO, DISTINÇÃO E EMULAÇÃO SOCIAL}

Além da identidade e da cidadania, outro aspecto importante a ser considerado quando pensamos sobre o consumo trata da diferenciação no consumo de mercadorias por indivíduos de classes sociais distintas. Para pensar este fato, nos serviremos de Bourdieu (1983), através dos conceitos habitus, gostos de classe e estilos de vida e dos autores Baudrillard (2014), Campbell (2001) e Lipovetsky (2007) que também trabalham com esta temática.

Bourdieu (1983, p. 82) define habitus como um "sistema de disposições duráveis e transponíveis que exprime, sob a forma de preferências sistemáticas, as necessidades objetivas das quais ele é o produto". Em outras palavras, habitus trata da predisposição de agir segundo modelos incorporados inconscientemente a partir da classe social a que se pertence, sendo que esses modelos são evidenciados por meios de gostos ou preferências que podem ser considerados distintivos.

Além disso, para o autor, as condições de existência nas quais o habitus é produzido são notoriamente expressas no estilo de vida. Desse modo, a correspondência observada entre

[...] o espaço das posições sociais e o espaço dos estilos de vida resulta do fato de que condições semelhantes produzem habitus substituíveis que engendram [...] práticas infinitamente diversas e imprevisíveis em seu detalhe singular, mas sempre encerradas nos limites inerentes as condições objetivas das quais elas são o produto e às quais elas estão objetivamente adaptadas (BORDIEU, 1983, p. 82-83, grifo do autor).

Com isso, para Bourdieu (1983), pessoas em semelhantes posições sociais tendem a apresentar semelhantes estilos de vida que, por sua vez, refere-se a um "conjunto unitário de preferências 
distintivas", de modo que o gosto "é a forma generativa que está no princípio do estilo de vida" (BOURDIEU, 1983, p. 83).

Logo, a distinção entre as classes poderia ser percebida tanto através daquilo que consomem, como através de suas preferências, visto que o que para uma determinada classe pode parecer distintivo ou supervalorizado, para outra é algo básico e elementar. Desse modo, o "consumo popular" se diferencia do "consumo de luxo" por aquele estar mais preso ao que é da ordem da necessidade enquanto esse, "liberado da urgência, se preocupa com a estética e com o estilo" (BOURDIEU, 1983, p. 85).

Campbell (2001), analisando as teorias que buscam explicar o consumismo moderno cita o instintivismo, o manipulacionismo e a perspectiva veblenesca, assim como suas coerências e contradições. Destas, abordaremos a perspectiva veblenesca que atribui ao consumidor um papel ativo na criação de suas necessidades e o manipulacionismo, que será abordado mais adiante.

A perspectiva veblenesca considera que o consumo de mercadorias não está ligado apenas à satisfação de necessidades, mas à significação sociocultural atribuída a elas. Desse modo, o consumo serve para indicar o nível de riqueza e o status social que se possui. Logo, o consumo de bens de luxo teria função de distinção e de emulação social, ou seja, de mobilidade social para cima. Associada à moda, a teoria da emulação explicaria a constante busca das pessoas por elevarem ou sustentarem um nível social, de modo que as tendências mudariam sempre para que as pessoas com menor poder aquisitivo não consigam acompanhar ou seguir a moda atual. Com isso, essas pessoas tenderiam a consumir produtos de luxo para se inserirem em determinados grupos ou se sentirem pertencentes a classes sociais mais abastadas, enquanto a elite consumiria para se destacar, para não ser confundida com pessoas de outras classes (CAMPBELL, 2001).

Bourdieu (1983, p.102) também aborda sobre o anseio por emular socialmente, quando trata da "dialética da pretensão e da distinção", em que pessoas em situação de pobreza denunciam sua condição através de seu estilo de vida e que, mesmo que consumam produtos ou adotem gostos ou preferências que considerem distintivos, mas desvalorizados por aqueles de posições sociais elevadas, acabam por demonstrar sua pretensão a pertencer a uma classe social mais abastada do que a que elas de fato pertencem.

Baudrillard (2014) também nos auxilia na compreensão do consumo como elemento distintivo ao atentar para a produção e manipulação dos significantes sociais. Como dissemos, esta produção se dá em dois momentos: o primeiro trata do processo de significação e comunicação e o segundo se refere ao processo de classificação e de diferenciação social, sobre o qual nos debruçaremos a seguir.

Segundo Baudrillard (2014), alguns mecanismos de guerra foram integrados na vida cotidiana, que sustentam uma constante disputa social por status, poder ou uma alta posição 
hierárquica, entretanto, essa disputa se dá no campo do simbólico. De acordo com o autor, o consumo, assim como a escola, é uma instituição de classe que transmite aos seus membros seus valores e signos distintivos pelos quais se reconhecem. Esses signos manipulados se mostram como valores estatuários no seio de uma hierarquia, na qual os objetos podem apenas "simular sua essência social", mas não podem ser utilizados a fim de pretender uma "salvação pelo consumo", de modo que alguém seja reconhecido como membro de uma classe com maior poder aquisitivo, pois não se trata apenas do objeto, mas da maneira de consumir, que também é distintiva. Assim, para Baudrillard (2014), as “classes superiores” comprovariam sua excelência no exercício da cultura e do poder.

A compreensão de Baudrillard sobre a impossibilidade de simular uma essência social vai de encontro com a teoria de Bourdieu sobre a distinção, haja vista que o autor considera que "As diferentes classes sociais se distinguem menos pelo grau em que reconhecem a cultura legítima do que pelo grau em que elas a conhecem" (BOURDIEU, 1983, p. 94).

Além disso, Baudrillard (2014) aborda a questão do crescimento econômico e do modo como este promove a introdução constante de novos produtos e a proliferação de qualidades do mesmo bem. Posto isto, para o autor, existe uma lei de distribuição e de renovação do material distintivo que ocorre de cima para baixo, isto é, com a disposição dos bens primeiro para as classes com maior poder aquisitivo e depois para as menos favorecidas. Para isto, ocorre uma redução nos preços dos produtos mais velhos ou ultrapassados que ficam desvalorizados para o mercado. Essa redução tem como objetivo agir contra o desperdício, além de preservar a distância social entre os consumidores. Tal lei, conforme o autor, só denota que as necessidades das classes mais pobres são sempre passíveis de atraso.

Baudrillard (2014) também desmistifica a crença da sociedade do crescimento como sendo sociedade da abundância e explica que se trata justamente do contrário. Na sociedade do crescimento existe uma relação necessária entre prestígio e penúria, posto que ambos estão dialeticamente relacionados. Logo, a sociedade do crescimento necessita da penúria estrutural para poder se manter. Compreendendo a abundância como o equilíbrio da produção humana e das finalidades humanas, o autor considera que as sociedades do crescimento são dominadas pela raridade e defendem a permanência dessa condição. Por conseguinte, o crédito se mostra na sociedade de consumo como possibilidade de acesso à abundância propagada, libertando os consumidores dos tabus da poupança e incitando-os ao consumo e ao modo de racionalidade capitalista (BAUDRILLARD, 2014).

Outro aspecto bastante importante explorado por Baudrillard (2014) trata-se do narcisismo e do uso deste como estratégia de marketing. Assim, tomando por base a moral comunicativa do consumo e a lei do material distintivo, compreendemos os objetos de consumo enquanto signos de diferenças que se referem aos estamentos nos quais as pessoas são classificadas e que as distinguem 
dos demais. Logo, para o autor, as relações dos sujeitos com os outros e consigo mesmos são mediadas pelo consumo, visto que o consumidor é levado a diferenciar-se mediante os objetos e as maneiras pelas quais consome e a investir na sua imagem individual enquanto forma de identificação e reconhecimento. Além disso, existe uma coação social para que as pessoas ajam em conformidade com seu padrão estatuário, pois aquelas que não se adequam a esse modelo - porque demonstram não portar ou conhecer os signos comuns a uma determinada classe ou portam signos referentes a classes menos valorizadas - são desprezadas pelos membros de uma determinada classe que os reconhecem como diferentes. Baudrillard (2014) também aponta para o fato de que essas classes se unem mais pelas diferenças com as demais do que pelas semelhanças entre seus membros, fenômeno esse chamado de aparidade pelo autor. Este fenômeno se assemelha ao narcisismo das pequenas diferenças exposto por Freud, em que o reconhecimento da diferença promove ódio e desprezo ao diferente.

Portanto, para Baudrillard (2014), o consumo enquanto valor de signo estaria sempre voltado para o outro à medida que serve como instrumento de comunicação social. Logo, mesmo quando o consumo possui dimensão privada, ele se dirige ao outro, seja a esse outro internalizado ou à imagem que se quer passar a ele sobre a sua personalidade.

Lipovetsky (2007), no entanto, critica a ênfase dada por esses teóricos à distinção e ao consumo como símbolo de ostentação. Para o autor, o consumo distintivo tinha mais força na segunda fase da sociedade de consumo. Já na terceira e atual, o consumo ganha valor pessoal e privado. Já não se consome para expor aos outros, mas para si, para satisfazer-se e identificar-se, para organizar e personalizar o seu espaço, de acordo com seu estilo e preferências. O consumidor nesta fase estaria mais atento às funcionalidades do produto, aos avanços tecnológicos e à necessidade de acompanhar essas mudanças, além do desejo de se reconhecer no que consome e reforçar seu estilo, bem como satisfazer-se com os prazeres disponíveis na vitrine.

A crítica de Lipovetsky (2007) sobre os excessos dos teóricos da distinção é bastante perspicaz, tendo em vista que o consumo não se dirige apenas ao outro em sua função comunicativa, mas também serve para a organização e a identificação de cada sujeito, podendo ser compreendido como fonte de prazer e satisfação, tal como veremos no tópico a seguir. Faz-se necessário, no entanto, destacar o caráter ilusório dessa dicotomia entre individual e social. Os aspectos sociais e individuais que sustentam a prática do consumo não se excluem, mas se retroalimentam, posto que eles estão relacionados dialeticamente, o que pressupõe uma relação de interdependência e complementariedade entre ambos. A construção da subjetividade é decorrente das interações com o outro e da incorporação de valores, crenças e ideologias que são construídas socialmente. Por outro lado, a construção desses valores sociais é decorrente da participação ativa de indivíduos que significam e modificam as estruturas e convenções sociais. Uma crítica aos fatores sociais do consumo que negue a dimensão 
da individualidade e a subjetividade dos consumidores se cega para aspectos centrais para a compreensão do consumo, e da constituição humana de forma mais geral. Com isso, podemos pensar como o consumo se relaciona com o prazer ou com a tão almejada felicidade.

\section{CONSUMO E FELICIDADE}

Além de estar vinculado a aspectos sociais como distinção, identidade e cidadania, o consumo também se relaciona a um aspecto subjetivo, cujo significado também é construído socialmente, que é a felicidade. Entre os valores consagrados pelo nosso tempo, um dos mais apregoados é a busca da felicidade. Todas as ações devem ser realizadas em prol dela e deve-se fugir de tudo que entrave a sua concretização. Tal fato está em parte presente no seguinte trecho da clássica carta de Epicuro:

Consideremos também que, dentre os desejos, há os que são naturais e os que são inúteis; dentre os naturais, há uns que são necessários e outros, apenas naturais; dentre os necessários, há uns que são fundamentais para a felicidade, outros, para o bem-estar corporal, outros, ainda, para a própria vida. E o conhecimento seguro dos desejos leva a direcionar toda escolha e toda recusa para a saúde do corpo e para a serenidade do espírito, visto que esta é a finalidade da vida feliz: em razão desse fim praticamos todas as nossas ações, para nos afastarmos da dor e do medo" (EPICURO, 2002, p. 35).

$\mathrm{Na}$ impossibilidade de vivermos apenas momentos de alegria, há discordâncias sobre o que seria a felicidade e como esta deve ser alcançada. Assim sendo, ora ela é percebida como um equilíbrio entre momentos bons e ruins, opinião defendida por Epicuro (2002), ora é percebida como a satisfação de todos os desejos, a vivência de diversos tipos de gozos e a constante obtenção de prazer. Esta segunda visão é explorada pela publicidade, que aposta cada vez mais no consumo emocional e que está baseada nos valores vigentes de um cotidiano confortável e fácil (LIPOVETSKY, 2007).

Para Bauman (2008), as promessas de felicidade da sociedade de consumo são falaciosas, pois ela promoveria a insatisfação dos consumidores, sendo esta uma condição necessária para a sua manutenção. Os produtos seriam fabricados com limitações previstas e prescritas, a fim de que os sujeitos tivessem que descartá-los e trocá-los por outros. Deste modo, a crítica do autor consiste no fato de considerar que, dada a impossibilidade de cumprimento de suas promessas, o consumo não traz felicidade, mas sim infelicidade.

Baudrillard (2014) também contribui com esta discussão ao trazer à baila a felicidade como referência primordial da sociedade de consumo. Consoante o autor, existe uma crença de que o crescimento econômico engendraria a democratização do consumo que, por sua vez, promoveria o bem-estar e a felicidade dos consumidores mediante a satisfação de seus desejos e necessidades. Tal crença se sustenta no advento do humanismo, pelo qual se justifica que o processo de produção e 
consumo estaria vivendo outro estado, voltado não apenas para as necessidades do mercado, mas para a satisfação dos consumidores. Entretanto, o autor considera que esta crença é falsa, pois o crescimento econômico é função da desigualdade. Uma vez que a ordem social não-igualitária e a estrutura do privilégio são fundamentais para a manutenção da sociedade do crescimento, essa “democratização" do acesso ocorre de forma marginal e segregatícia. Também vale lembrar, como já destacamos anteriormente, que, de acordo com Baudrillard (2014) essas necessidades, ou melhor, esse sistema de necessidades é produzido a fim de atender à demanda do mercado e não ao prazer individual, sustentando com isso o processo de produção e consumo.

O autor também se utiliza do conceito de prazer para desmistificar a noção de felicidade atrelada ao consumo. Baudrillard (2014) se utiliza da compreensão de consumo de Lévi-Strauss, que o considerava como fato social, por não se restringir às concepções de natureza, satisfação, prazer, mas ao código de signo de diferenças. Lévi-Strauss fala sobre como a socialização desloca a dimensão do prazer do nível natural ou biológico para o nível social, por meio de signos. Contudo, Baudrillard (2014) interpreta essa mudança de forma crítica, o que nos remete ao deslocamento já anunciado por Marx e Debord do valor de uso para a forma de valor ou o fetiche da mercadoria. Para ele, o prazer definiria o consumo para si, como autônomo e final, sendo percebido como um fim em si mesmo. Nisso consiste a dimensão falaciosa da felicidade consumista apontada por Baudrillard (2014), porque a função de prazer não se refere à satisfação do consumidor, que está atrelada para ele ao valor de uso, mas a função de produção, isto é, a manutenção de um sistema produtivo que concebe o consumo como trabalho social. Esta dimensão também foi abordada por Huxley, como podemos observar no fragmento a seguir: “- E esse [...] é o segredo da felicidade e da virtude: amarmos o que somos obrigados a fazer. Tal é a finalidade de todo condicionamento: fazer as pessoas amarem o destino social de que não podem escapar.” (HUXLEY, 2009, p. 44).

Lipovetsky (2007), no entanto, contrapõe essa ideia considerando felicidade e prazer como elementos distintos. Para ele, o consumidor não espera a felicidade no ato do consumo, ele busca prazer e conforto, e frequentemente consegue o que quer. Vendem-se experiências na forma de sensações, sabores e novidades, de modo que as despesas com lazer vêm crescendo cada vez mais. Para ele, os consumidores estão mais informados sobre o que consomem, comparam e analisam a relação custo-benefício dos produtos, de modo que a prática longe de ser irracional, é pensada e bem analisada, salvo os excessos consumistas. $\mathrm{O}$ autor também considera que o consumo seria uma forma de liberdade, na qual o "hiperconsumidor" rejeita a rotina e a coisificação do eu, pela possibilidade de realizar escolhas e se ver como sujeito (LIPOVETSKY, 2007).

Apesar dos diferentes modos de compreender felicidade e consumo por Baudrillard (2014) e Lipovestsky (2007), há um ponto em que ambos os autores concordam: você pode escolher o que vai 
consumir, mas você não tem a escolha de não consumir. Esta obrigatoriedade, como aponta Lipovetsky (2007), mesmo em fase de hiperconsumo, já incomoda alguns segmentos da população que criam outras formas de responder aos ditames da sociedade do consumo, por meio de atitudes mais críticas como o movimento denominado "consumo consciente".

Assim, para uma maior compreensão sobre os fatores que constituem o fenômeno do consumo, faz-se necessário discorrer sobre o papel atribuído à mídia na construção de gostos e ideais. Posto isto, abordaremos no próximo tópico a influência exercida pela Indústria Cultural, ou os meios de transmissão midiáticos, no consumo de mercadorias.

\section{INDÚSTRIA CULTURAL, IDEOLOGIA E MÍDIA}

Iniciaremos este tópico com algumas ideias de Adorno e Horkheimer (2006) sobre a indústria cultural que julgamos fundamentais para esta breve análise sobre a influência dos meios midiáticos no consumo. Em seguida, relacionaremos estas ideias com as concepções de mídia e ideologia para Thompson (1995, 1998) e Guareschi (1992, 2000).

O conceito de Indústria Cultural é introduzido por Adorno e Horkheimer (2006) na obra Dialética do Esclarecimento, em que os autores retratam algumas características e funções dos massmedia ou meios de comunicação de massa (cinema, televisão, rádio, discos, entre outros). Consoante os autores, a indústria cultural, que se autointitula como uma "indústria", segue a mesma lógica e os mesmos princípios e valores das demais indústrias capitalistas, padronizando seus produtos por meio da produção em série com vista ao maior faturamento possível. Liberados da necessidade de terem que se apresentar como arte, cinema e rádio perderiam tanto a originalidade de sua contribuição quanto a experiência estética, marcada pela atividade contemplativa e reflexiva característica das obras de arte, para se apresentarem como instrumentos reprodutores de uma racionalidade técnica instrumental, valorizada e preferida em detrimento de uma racionalidade prática ou reflexiva.

Assim, de acordo com Adorno e Horkheimer (2006), a indústria cultural retrataria e reproduziria a vida cotidiana estabelecida pelo capitalismo, promovendo adequação e conformidade a esse sistema, mediante a constante repetição de seu conteúdo padronizado, de modo que fosse possível prever quais seriam os próximos passos, acordes, ou possibilidades de vida. Esse modo de viver pregado pelo capitalismo é compreendido como a única ou a melhor forma de vida possível, o que leva as pessoas a buscar se enquadrar nessa lógica e a viver conforme os padrões que sua posição lhes determina, em relação ao trabalho, ao consumo, à diversão e ao tempo livre. "É a indústria cultural que fixa o divertimento e os seus horários. E o indivíduo se submete. Como se submete às regras do 'tempo livre', que é o tempo programado pela indústria cultural." (REALE; ANTISERI, 
2003, p. 845). Além disso, a diversão e o entretenimento, percebidos como os principais objetivos dos produtos da indústria cultural, não seriam mais do que o prolongamento do trabalho no capitalismo tardio, já que o prepara para as atividades laborais com sua reprodução do mesmo. Distrai ao mesmo tempo em que exercita essa racionalidade técnica, evitando ao máximo o esforço intelectual (ADORNO; HORKHEIMER, 2006).

Esta conformidade com o sistema também pode ser percebida como conformidade com as tipificações e estratificações sociais, de forma que o consumo também deve se dar de modo hierarquizado, em consonância com o seu nível social. "Cada qual deve se comportar, como que espontaneamente, em conformidade com seu level, previamente caracterizado por certos sinais, e escolher a categoria dos produtos de massa fabricada para seu tipo." (ADORNO; HORKHEIMER, 2006, p. 102). Essa hierarquia de qualidades dos produtos serve também como forma de qualificar e quantificar, por meio dos valores dos produtos, as categorias de consumidores. Logo, os produtos são projetados de acordo com a tipificação dos consumidores, isto é, nível social, idade, identificações e estilo.

Adorno e Horkheimer (2006, p. 108) consideram essa tipificação como uma exigência do liberalismo, que "censura a falta de estilo". A necessidade de adoção de um estilo demanda que esse estilo seja alimentado por meio de mercadorias que o representam, como já dissemos anteriormente. Além disso, o estilo também pode ser compreendido como uma forma de padronização das pessoas, de forma que aqueles que não se sujeitarem a este enquadramento poderão ser punidos com a exclusão econômica e social. Assim, conforme Reale e Antiseri (2003, p. 845), “[...] a indústria cultural não vincula propriamente uma ideologia: ela própria é ideologia, a ideologia da aceitação dos fins estabelecidos por 'outros', isto é, pelo sistema.”.

Vale salientar que o conceito de ideologia aqui tem a mesma conotação negativa atribuída por Marx, conforme explanaremos a seguir. Assim, de acordo com Adorno e Horkheimer (2006), a indústria cultural enquanto uma ideologia legitima o sistema capitalista, bem como os modos de vida que ele delimita e as desigualdades nas quais se sustenta. Apesar disso, o público ou a massa insistiria nessa ideologia que os escraviza, ansiando por conhecer e adquirir as novidades do capitalismo, a fim de se olvidarem da opressão a que estão subjugados. A contradição representada pelo culto ao opressor faz com que os autores considerem que a recepção desta ideologia se dá de maneira passiva pelos consumidores da indústria cultural, que limitados a uma racionalidade técnica, não conseguiriam ver além do que é propagado. 
Esta concepção de que a recepção das mensagens veiculadas pelos "meios de comunicação de massa" se dá de forma passiva é bastante questionada por alguns autores, dentre eles Thompson (1995) e Campbell (2001), como veremos a seguir, que consideram que o público tem sua parcela de contribuição na recepção das mensagens, elaborando um significado em torno delas a partir de seu repertório de conhecimento. No entanto, antes de abordarmos a concepção de mídia para Thompson (1995), julgamos necessário nos reportarmos ao conceito de ideologia e em como ele foi explorado pelos diferentes autores.

Como Guareschi (1992) bem destaca, o conceito de ideologia é bastante escorregadio, de modo que é sempre um desafio falar sobre ele, devido às diversas significações que lhe foram atribuídas. Entretanto, deter-nos-emos aqui na contribuição de Karl Marx, que trabalha com a concepção negativa de ideologia.

Em “A ideologia alemã”, Marx e Engels (1973) retratam a ideologia como uma forma de obscurecimento da realidade, mistificação ou engano, mostrando como a filosofia idealista alemã, ao se prender às ideias abstratas, desconsiderava a realidade material e os problemas de sua época. Assim, a ideologia é entendida aqui em sua concepção negativa, isto é, como um saber falso e enganador. Marx também compreendia a ideologia como a superestrutura em sua metáfora do edifício, compondo assim o conjunto de ideias, crenças, valores e leis de uma época. Para ele, as ideias dominantes de uma época eram as ideias da classe dominante, que determinariam as leis, crenças e costumes a serem seguidos (QUINTANEIRO, 2002; HAGUETTE, 2003).

Desse modo, são nessas concepções postuladas por Marx que se apoiam Adorno e Horkheimer (2006) ao considerar a indústria cultural como uma ideologia, pois, ao mesmo tempo em que ela destaca as benesses do capitalismo, esconde as consequências desse sistema, a falsidade de suas promessas e o preço que se paga para fazer parte dele.

Thompson (1995) também adota estas concepções marxianas com algumas ressalvas e modificações. Para Marx, de acordo com o autor, as relações de dominação e subordinação de classe constituiriam os principais eixos da desigualdade e exploração nas sociedades humanas, particularmente, nas sociedades capitalistas. Já Thompson (1995) considera a dominação de classe como uma forma de dominação e subordinação e como sendo um eixo de desigualdade e exploração. Ele amplia o conceito de dominação de Marx, relacionado à dominação de classe, entendendo que a dominação também estaria relacionada com o sentido atribuído às relações entre homens e mulheres, entre um grupo étnico e outro, entre estados-nação hegemônicos e estados-nação periféricos. Além disso, Marx supervalorizaria o papel da tradição na manutenção das relações sociais, que seriam estabelecidas antes e independentemente da mobilização dos sentidos das formas simbólicas. Já para Thompson, as formas simbólicas 
não são meramente representações que servem apenas para articular ou obscurecer relações sociais ou interesses que são constituídos fundamentalmente e essencialmente em um nível pré-simbólico: ao contrário, as formas simbólicas estão, contínua e criativamente, implicadas na constituição das relações sociais como tais (THOMPSON, 1995, p.78).

Destarte, para Thompson (1995, p. 76). “estudar ideologia é estudar as maneiras como o sentido serve para estabelecer e sustentar relações de dominação". O sentido a ser analisado na teoria de Thompson é o sentido mobilizado pelas formas simbólicas, isto é, "um amplo espectro de ações e falas, imagens e textos, que são produzidos por sujeitos e reconhecidos por eles e outros como construtos significativos" (THOMPSON, 1995, p. 79). Logo, segundo o autor, "a análise da ideologia está primeiramente interessada nas maneiras como as formas simbólicas se entrecruzam com relações de poder" (THOMPSON, 1995, p. 75). Também é importante ressaltar que, para Thompson (1995), os fenômenos simbólicos não são ideológicos enquanto tais, mas quando empregados em um contexto particular em que servem para criar ou manter relações de dominação.

Guareschi (2000) se baseia na concepção de Thompson para sua análise da ideologia, considerando-o como "o autor que melhor trata a problemática da ideologia" (2000, p. 93). Contudo, Guareschi (1992) propõe uma forma mais ampla de caracterizar os usos desse termo, considerando que a ideologia poderia ser compreendida principalmente por dois eixos, sendo o primeiro valorativo, que compõe as dimensões positiva e negativa, e o segundo eixo seria conteúdo $X$ prática, que compreenderia as dimensões estática e dinâmica. Em relação ao primeiro eixo, na dimensão positiva ou neutra, a ideologia é percebida como um conjunto de ideias, valores, ou como uma cosmovisão; e na dimensão negativa ou crítica, ela é constituída por ideias distorcidas, enganadoras, sendo representada como algo "abstrato ou impraticável" ou como algo "ilusório ou errôneo", que impede que se chegue ao conhecimento da verdade, tal como as quatro classes de ídolos citados por Bacon ${ }^{4}$, expressando interesses dominantes e servindo para sustentar relações de dominação (GUARESCHI, 2000, p. 91). Já em relação ao eixo conteúdo X prática, na dimensão estática se compreende ideologia como conteúdo, ou seja, como algo fixo e imutável; e na dimensão dinâmica, ela é percebida como algo passível de transformação ou capaz de criar e transformar a realidade (GUARESCHI, 1992). Este último eixo também é descrito em outro trabalho pelo autor como compondo dois grandes conjuntos de ideologias, que são:

ideologias como sendo algo materializado, onde a ideologia está corporificada na própria ideia, na forma simbólica, ou mesmo concretizada numa instituição, como a escola ou a família, e ideologia como modo e estratégia, onde a ideologia é vista como uma prática, uma maneira como as formas simbólicas servem para criar e manter as relações sociais entre pessoas (GUARESCHI, 2000, p. 91-92).

\footnotetext{
4 “Esses ídolos são os da caverna: nossas idiossincrasias, caráter; da tribo: superstições, paixões; da praça: as inter-relações humanas, principalmente através da linguagem; e os ídolos do teatro: a transmissão das tradições e doutrinas dogmáticas e autoritárias, através do teatro, que seriam, hoje, os Meios de Comunicação Social.” (IBIDEM, p. 170).
} 
Guareschi (2000) separa ideologia em duas linhas, uma horizontal que delimita a dimensão positiva (acima) e a dimensão negativa (abaixo) e outra vertical que separaria a dimensão material, concreta (à esquerda) da dimensão prática, dinâmica (à direita). A junção dessas linhas corresponderiam a 4 quadrantes com as diversas concepções existentes de diversos autores que abordaram o tema, desde Destutt de Tracy ${ }^{5}$ até Thompson.

Figura 1: Ideologia

IDEOLOGIA

\section{Eixos e Campos}

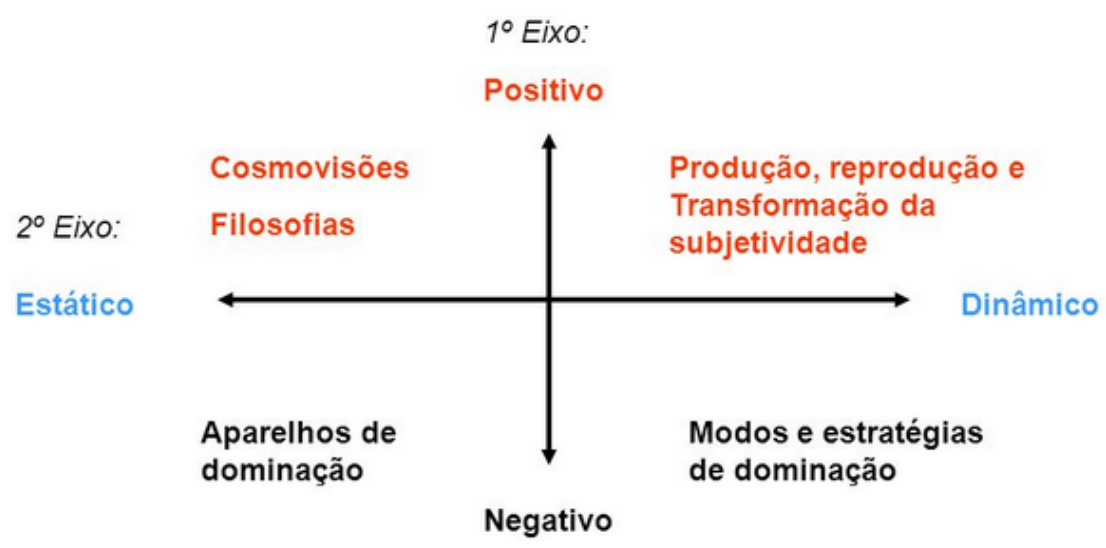

Fonte: GUARESCHI, Pedrinho. Mídia, educação e cidadania. Caxias do Sul - RS, 2013; Disponível em: $<$ http://slideplayer.com.br/slide/68246/ > . Acesso em: 3 nov. 2017.

Desses quadrantes, o autor prioriza o quarto, que representaria a ideologia em sua dimensão negativa e prática, tal como foi elaborada por Thompson. Guareschi (2000) a considera como a concepção mais interessante de ideologia, pois, ao analisarmos se determinadas ideias podem ser falsas e enganadoras ou prejudicar as pessoas que nos cercam, nosso trabalho se torna mais prático e útil à ciência e à sociedade.

Para Thompson (1998, p. 13), “o uso dos meios de comunicação implica a criação de novas formas de ação e de interação do mundo social, novos tipos de relações sociais e novas maneiras de relacionamento do indivíduo com os outros e consigo mesmo". Além disso, o impacto das formas simbólicas na criação ou construção dessas novas formas de ação ou interação vai depender dos meios técnicos utilizados no processo de transmissão cultural, que seria o processo pelo qual as formas simbólicas são transmitidas dos produtores aos receptores (THOMPSON, 1995).

\footnotetext{
${ }^{5}$ Destutt de Tracy teria sido o primeiro a utilizar o termo ideologia, compreendendo-a como o estudo científico das ideias e, portanto, a ideologia deveria ser a mãe de todas as ciências. Por questões políticas, Napoleão Bonaparte desmereceu o trabalho e a pessoa de de Tracy, atribuindo ao termo ideologia uma conotação negativa, como sendo algo falso e enganador (THOMPSON, 1995).
} 
O meio técnico é o substrato material das formas simbólicas, isto é, o elemento material com que, ou por meio do qual a informação ou o conteúdo simbólico é fixado e transmitido do produtor para o receptor. Todos os processos de intercâmbio simbólico envolvem um meio técnico de algum tipo (THOMPSON, 1998, p. 26).

O uso dos meios técnicos implica um determinado conhecimento sobre o funcionamento dos mesmos para que se possa codificar ou decodificar o conteúdo das formas simbólicas, por exemplo, saber ler/escrever em um papel, saber usar um celular, saber utilizar um gravador, ou uma televisão, etc., de modo que uns podem exigir mais conhecimento técnico do que outros. Além disso, os meios técnicos possibilitam certo grau de fixação e reprodução das formas simbólicas, que pode ser maior ou menor dependendo do meio utilizado (por exemplo: a escultura pode apresentar alto grau de fixação e baixo grau de reprodução, enquanto um jornal pode apresentar alto grau de fixação e alto grau de reprodução), além de possibilitar diferentes níveis de participação de produtores e receptores através da codificação e decodificação das formas simbólicas, por exemplo, no uso do celular há uma relação dialógica, onde ambos participam de semelhante modo, enquanto em um programa televisivo, a transmissão é de mão única, tendo baixo, embora exista, grau de participação do receptor, para ele, os mais importantes meios de difusão estão relacionados com a transmissão televisiva (THOMPSON, 1995).

Com o desenvolvimento das telecomunicações (...) grande distanciamento espacial pode ser conseguido sem o transporte físico das formas simbólicas, dando origem a novas possibilidades de transmissão cultural e, com isso, ao exercício do poder através de distâncias temporais (THOMPSON, 1995, p. 226).

Outro conceito importante para o estudo da mídia é o conceito de "comunicação de massa", que se refere à "produção institucionalizada e difusão generalizada de bens simbólicos através da fixação e transmissão de informação ou conteúdo simbólico" (THOMPSON, 1998, p. 32). Thompson (1995) considera que o desenvolvimento da comunicação de massa aumenta, consideravelmente, a área de atuação da ideologia nas sociedades modernas, já que as formas simbólicas seriam transmitidas possivelmente a um extenso e variado público e estariam dispersas no tempo e no espaço.

Por outro lado, de acordo com Thompson (1995), o termo comunicação de massa pode ser considerado enganador por sugerir uma dimensão quantitativa, que se referiria a um elevado número de pessoas que teriam acesso a determinado conteúdo, o que não é verdade, posto que alguns programas, mesmo estando potencialmente disponíveis para ampla audiência, são acessados por um pequeno e especializado número de pessoas; e também por parecer se referir a amontoados de pessoas, inertes e indiferenciados, o que também não é verídico, posto que, para ele, a atividade de recepção depende do contexto em que esse conteúdo é recebido, envolvendo graus diferenciados de habilidades de atenção, prazer, criticidade, etc., de modo que "o processo de recepção é uma atividade muito mais 
ativa, criativa, e crítica do que muitos analistas estão inclinados a supor" (THOMPSON, 1995, p. $320)$.

Nisto a concepção de Thompson converge com a explicitada por Campbell (2001) em sua análise do manipulacionismo de Galbraith. Campbell (2001) critica a teoria de que as necessidades seriam criadas pela mídia, em especial pelas propagandas, de modo que essas seduziriam os sujeitos para consumir, seja através de um "controle subliminal", injetando necessidades, ou devido ao fato de que alguns consumidores seriam "hipersugestionáveis", sendo influenciados apenas pelo contato ou imagem do produto. Para ele, essas teorias considerariam como manipulação o fato de as propagandas não venderem um produto apenas por sua utilidade, mas evocarem um valor simbólico a esses produtos, associando-os a um padrão de vida, de estilo ou de personalidade. Elas também criticariam o consumo motivado pela emoção, que extrapolaria o cálculo racional, representando outra forma de manipulação.

Para Campbell (2001) as propagandas exercem sim alguma influência em relação ao consumo de mercadorias, mas o que seria de fato manipulado pela propaganda seriam os símbolos associados ao consumo e não as necessidades que seriam implantadas, a fim de que aqueles atinjam as motivações e interesses coletivos. Logo, para ele, a questão de fato seria entender como a recepção desses símbolos ou mensagens leva à criação de necessidades pelo consumidor, considerando que o receptor teria um papel ativo na produção de suas necessidades.

Por conseguinte, vários fatores estão relacionados ao modo como as pessoas recebem essas informações transmitidas pelas diversas mídias, desde condições individuais, e nível de amadurecimento crítico de cada um, a condições socioeconômicas, como o contato que possuem com essa tecnologia. Está claro que a mídia constrói gostos e preferências que circundam o imaginário social, justamente por se adequarem a valores do nosso tempo, como o culto ao novo, ao prazer, à velocidade e à informação. Entretanto, essas imagens não atingem a todos de maneira uniforme. Cada um constrói seus próprios sentidos em torno daquilo que ouve e que vê, sendo que esses não deixam de estar relacionados aos valores defendidos pelos grupos dos quais faz parte.

\section{CONSIDERAÇÕES}

De acordo com a literatura aqui explanada, o consumo se mostra como principal atividade das sociedades atuais, estando relacionado a diversos fatores que compõem a vida social, como identidade, distinção, cidadania e felicidade. Nas sociedades de consumo, de acordo com Baudrillard (2014), são produzidos sistemas de necessidades que motivam e sustentam os excessos consumistas em nome do crescimento econômico e da falsa noção de que este possibilitaria a democratização do 
consumo e, consequentemente, a construção de uma sociedade da abundância e do bem-estar para todos. No entanto, consoante o autor, o crescimento econômico é função da desigualdade, visto que a estrutura do privilégio e da raridade são elementos fundamentais para a manutenção desse tipo de sociedade.

Apesar de reconhecermos a relevância de tal compreensão, não podemos considerar os fenômenos do consumo e do consumismo unicamente como a satisfação de necessidades artificialmente produzidas, mas também devemos analisar os aspectos subjetivos e sociais que fomentam e levam a reprodução dessa sociedade do consumo. Para além disso, cabe ressaltar que o consumo também é um modo de identificação, reconhecimento, afirmação e comunicação, logo, seria ingenuidade considerar os consumidores apenas como vítimas dessa sociedade ou pessoas manipuladas por esse sistema. Apesar da influência dos meios que incitam e promovem o consumo, esta cultura não se sustenta apenas pelo esforço das indústrias e dos meios de comunicação de massa, mas também pelo desejo crescente e de certo modo, consciente, das pessoas de fazerem parte dessa sociedade e de serem aceitas e reconhecidas por ela.

\section{REFERÊNCIAS}

ADORNO, T. W.; HORKHEIMER, M. Dialética do Esclarecimento: fragmentos

filosóficos. Tradução de Guido Antonio de Almeida. Rio de Janeiro: Jorge Zahar, 2006.

BAUDRILLARD, J. A sociedade de consumo. Lisboa: Edições 70, 2014.

BAUMAN, Z. Vida para consumo: a transformação das pessoas em mercadoria. Rio de Janeiro: Jorge Zahar, 2008.

BAUMAN, Z. Identidade: entrevista a Benedetto Vecchi. Rio de Janeiro: Jorge Zahar, 2005.

BOURDIEU, P. Gostos de classe e estilos de vida. ORTIZ, R. (org.). Pierre Bourdieu. col. Sociologia. São Paulo: Ática, 1983. p. 83-121.

CAMPBELL, C. A ética romântica e o espírito do consumismo moderno. Rio de Janeiro: Rocco, 2001.

CANCLINI, N. G. Consumidores e cidadãos: conflitos multiculturais da globalização. Rio de Janeiro: Editora UFRJ, 1997. 
CORTEZ, A. T. C. Consumo e desperdício: as duas faces das desigualdades. In: ORTIGOZA, S. A. G., CORTEZ, A. T. C., orgs. Da produção ao consumo: impactos socioambientais no espaço urbano [online]. São Paulo: Editora UNESP; São Paulo: Cultura Acadêmica, 2009, p. 35-62.

DEBORD, G. A sociedade do espetáculo. Ebooks Brasil, 2003. Disponível em: $<$ http://www.ebooksbrasil.org/adobeebook/socespetaculo.pdf $>$. Acesso em: 10 fev. 2016.

EPICURO. Carta sobre a felicidade: (a Meneceu). São Paulo: Editora UNESP, 2002.

GUARESCHI, P. A Ideologia. In: STREY, M. N. Psicologia social contemporânea. Petrópolis: Vozes, 2000. p. 89-103.

GUARESCHI, P. Sociologia da prática social. 3. ed. Petrópolis: Vozes 1992.

HAGUETTE, A. A sociologia e você. Fortaleza, Book Editora, 2003.

HUXLEY, A. Admirável mundo novo. São Paulo: Globo, 2009.

LIPOVETSKY, G. A felicidade paradoxal: ensaio sobre a sociedade de hiperconsumo. São Paulo: Companhia das Letras, 2007.

MAINGUENEAU, D. Análises de Textos de Comunicação. São Paulo: Cortez, 2001.

MARX, K.; ENGELS, F. A Ideologia Alemã. 10. ed. São Paulo: Hucitec, 1973.

MARX, K. Contribuição à crítica da economia política. São Paulo: Expressão Popular, 2008.

MARX, K. O capital. Livro 1. São Paulo: Boitempo, 2012.

ORTIGOZA, S. A. G. Da produção ao consumo: dinâmicas urbanas para um mercado mundial. In: ORTIGOZA, Silva Aparecida Guarnieri, CORTEZ, Ana Teresa C.,orgs. Da produção ao consumo: impactos socioambientais no espaço urbano [online]. São Paulo: Editora UNESP; São Paulo: Cultura Acadêmica, 2009. 146 p.

QUINTANEIRO, T. Um toque de clássicos: Marx, Durkheim e Weber. 2. ed. Belo Horizonte: Ed. UFMG, 2002.

REALE, G; ANTISERI, D. História da Filosofia. Vol. 3. São Paulo: Paulus, 2003. 
THOMPSON, J. B. Ideologia e Cultura Moderna: Teoria social crítica na era dos meios de comunicação de massa. 9 ed. Petrópolis, RJ: Vozes, 1995.

THOMPSON, J. B. A Mídia e a Modernidade: Uma teoria social da mídia. 13 ed. Petrópolis, RJ: Vozes, 1998.

Recebido em: 04-1-2018

Histórico Revisado em: 18-5-2018

Aceito em: 23-5-2018 